\title{
PENGELOLAAN ARSIP DINAMIS PADA DINAS PERPUSTAKAAN DAN KEARSIPAN KOTA PALANGKA RAYA
}

\section{Management of Dynamic Archives at the Library and Archives Office of the City of Palangka Raya}

\section{Irwani* $^{*}$}

Ika

Universitas Muhammadiyah

Palangkaraya, Palangka Raya,

Central Kalimantan, Indonesia

email:

irwani@umpalangkaraya.ac.id
Kata Kunci:

Pengelolaan

Arsip Dinamis

Arsip

\section{Keywords:}

Management

Dynamic Archive

Files

Accepted

August 2017

Published

October 2017

\begin{abstract}
Abstrak
Penelitian ini bertujuan untuk mengetahui, I) pengelolaan arsip dinamis, 2) faktorfaktor yang mempengaruhi pengelolaan arsip, 3) hambatan-hambatan yang dihadapi dalam pengelolaan arsip di Dinas Perpustakaan dan Kearsipan Kota Palangka Raya. Penelitian ini menggunakan metode penelitian kualitatif. Informan dalam penelitian ini adalah Staf Bagian Tata Usaha, Staf Seksi Pengelolaan arsip dinamis, serta arsiparis di Dinas Perpustakaan dan Kearsipan Kota Palangka Raya. Data dikumpulkan melalui observasi, wawancara, dan dokumentasi. Langkah-langkah dalam menganalisis data adalah reduksi data, penyajian data, dan penarikan kesimpulan. Pemeriksaan keabsahan data dilakukan dengan uji kredibilitas dengan strategi meliputi perpanjangan pengamatan, ketekunan penelitian, triangulasi, diskusi teman sejawat, dan member checking. Hasil penelitian ini menunjukkan bahwa secara umum pengelolaan arsip dinamis pada Dinas Perpustakaan dan Kearsipan Kota Palangka Raya meliputi: penciptaan arsip dinamis yang meliputi penciptaan surat masuk dan surat keluar. Penggunaan arsip yang meliputi peminjaman arsip yang menggunakan lembar pinjam arsip dan penemuan kembali arsip yang menggunakan kartu kendali serta daftar pencarian arsip. Hambatan dalam pengelolaan arsip berupa kurangnya ruangan kearsipan, kurangnya anggaran dalam pengadaan fasilitas arsip, dan kurangnya jumlah personil petugas arsip.
\end{abstract}

\begin{abstract}
This study aims to find out, I) the management of dynamic records, 2) the factors that influence the management of documents, 3) the obstacles faced in archive management in the Library and Archives Office of the City of Palangka Raya. This study used qualitative research methods. The informants in this study were Administrative Section Staff, Dynamic Records Management Section Staff, and archivists at the Library and Archives Service Office of Palangka Raya City. Data is collected through observation, interviews, and documentation. The steps in analyzing data are data reduction, data presentation, and conclusion drawing. Checking the validity of the data is done by testing credibility with the strategy, including extending observations, research perseverance, triangulation, peer discussion, and member checking. The results of this study indicate that in general the management of dynamic records in the Library and Archives Office of the City of Palangka Raya includes: the creation of dynamic archives which include the creation of incoming letters and outgoing letters. Use of archives which include borrowing archives that use borrowed archive sheets and rediscovering archives that use a control card and archive search list. Obstacles in the management of records in the form of lack of filing rooms, lack of budgets in the procurement of archival facilities, and the lack of an archive staff.
\end{abstract}

\section{PENDAHULUAN}

Instansi pemerintah daerah seperti kelurahan merupakan salah atau contoh instansi pemerintah yang melaksanakan pelayanan. Kelurahan adalah wilayah kerja lurah sebagai perangkat daerah kabupaten/kota dalam wilayah kerja kecamatan. Dalam konteks otonomi daerah di Indonesia, kelurahan merupakan wilayah kerja lurah sebagai perangkat daerah kabupaten atau kota.
Kelurahan merupakan unit pemerintah terkecil setingkat dengan desa. Kelurahan dilihat dari sistem pemerintahan Indonesia merupakan ujung tombak dari pemerintahan daerah yang langsung berhadapan dengan masyarakat luas. Citra birokrasi pemerintahan secara keseluruhan akan banyak ditentukan oleh Pelayanan publik tersebut. Masyarakat yang berada di kelurahan diperlukan aparatur pelayanan yang profesional. 
Kelurahan merupakan instansi yang memberikan pelayanan kepada masyarakat termasuk pembuatan surat keterangan tidak mampu (SKTM). Untuk memperoleh Surat keterangan tidak mampu masyarakat harus di kategorikan sebagai masyarakat yang tidak mampu yaitu suatu kondisi di mana masyarakat tersebut tidak memiliki sarana lingkungan yang belum memadai, dengan kualitas pemukiman dan perumahan yang jauh dibawah standar kelayakan serta mata pencaharian yang tidak menentu, dan juga harus mempunyai Kartu Tanda Penduduk (KTP) dan Kartu Keluarga (KK) yang berasal dari daerah kelurahan dan desa tersebut dan surat pernyataan tidak mampu dari RT/RW setempat. Surat Keterangan Tidak Mampu Juga digunakan sebagai Persyaratan pembuatan KMC (Kartu Mura Cerdas) pada Perbub No.33 Tahun 2015 selain digunakan untuk Persyaratan Pembuatan Kartu Mura Cerdas, Surat Keterangan Tidak Mampu Juga digunakan untuk Persyaratan pembuatan Kartu Indonesia Pintar. Masih tingginya angka kemiskinan di Indonesia membuat masyarakat yang kurang mampu mengajukan permohonan untuk pembuatan Surat Keterangan Tidak Mampu (SKTM) dengan harapan kebutuhan hidup mereka lebih mudah dengan adanya Surat Keterangan Tidak Mampu hal ini dilihat dari angka kemiskinan di Kelurahan Muara Tuhup berjumlah 420 orang dengan I40 KK (Kepala Keluarga) tergolong miskin.

Pelayanan publik pada dasarnya merupakan tindakan yang dilakukan kepada masyarakat dalam bentuk pelayanan sehingga dapat memenuhi kebutuhan dari masyarakat. Menurut Kurniawan (Mulyadi, 2016) Pelayanan Publik dapat diartikan sebagai pemberian pelayanan (melayani) keperluan orang atau masyarakat yang mempunyai kepentingan pada organisasi itu sesuai dengan aturan pokok dan tata cara yang telah ditetapkan. Berikutnya menurut, Sinambela (Pasolong, 2016) Pelayanan Publik adalah sebagai setiap kegiatan yang dilakukan oleh pemerintah terhadap sejumlah manusia yang memiliki setiap kegiatan yang menguntungkan dalam suatu kumpulan atau kesatuan, dan menawarkan kepuasan meskipun hasilnya tidak terikat pada suatu produk secara fisik.

Kualitas pelayanan pada dasarnya merupakan suatu tindakan yang menggambarkan tingkat keberhasilan suatu pelayanan yang diberikan kepada masyarakat. Menurut, Crosby, dkk (Waluyo 2007) mendefinisikan kualitas pelayanan adalah penyesuaian terhadap perincian - perincian (conformance to specification) dimana kualitas ini dipandang sebagai derajat keunggulan yang ingin dicapai. Dilakukan kontrol terus - menerus dalam mencapai keunggulan tersebut dalam rangka memenuhi kebutuhan pengguna jasa. Berikutnya menurut, Sampara (Hardiyansyah, 20II) mengemukakan bahwa kualitas pelayanan adalah pelayanan yang diberikan kepada pelanggan sesuai dengan standar pelayanan yang telah dibakukan sebagai pedoman dalam memberikan layanan.

Menurut Zeithaml et.al. (Hardiyansyah, 20II: 43) mengatakan bahwa ada 4 (empat) jurang pemisah yang menjadi kendala dalam pelayanan publik, yaitu sebagai berikut:

I. Tidak tahu apa yang sebenarnya diharapkan oleh masyarakat;

2. Pemberian ukuran yang salah dalam pelayanan masyarakat;

3. Keliru penampilan diri dalam pelayanan publik itu sendiri

4. Ketika membuat perjanjijan terlalu berlebihan atau pengobralan.

Berdasarkan pendapat ahli di atas dapat di tegaskan bahwa faktor yang mempengaruhi kualitas pelayanan adalah tidak tahu apa yang di inginkan oleh masyarakat sehingga melakukan pengukuran yang salah pada pelayanan yang diberikan kepada masyarakat dan membuat perjanjian yang berlebihan serta keliru dalam penampilan diri dalam memberikan pelayanan public.

Zeithaml dkk dalam (Hardiyansyah 20II) kualitas pelayanan dapat diukur dari 5 dimensi, yaitu : Tangible 
(berwujud), Reliability (kehandalan), Responsiviness (ketanggapan), Assurancce (jaminan), Empaty (empati). Sinambela, dkk dalam (Pasolong 2016) mengatakan bahwa kualitas pelayanan prima tercermin dari : (I) transparansi, yaitu pelayanan yang bersifat terbuka, mudah dan dapat diakses oleh semua pihak yang membutuhkan dan disediakan secara memadai serta mudah dimengerti, (2) akuntabilitas, yaitu pelayanan dapat di pertanggung jawabkan sesuai dengan ketemtuan peraturan perundang-undangan, (3) kondisional, yaitu pelayanan yang sesuai dengan kondisi dan kemampuan pemberi dan penerima pelayanan dengan tetap berpegang pada prinsip efisiensi dan efektivitas, (4) partisipatif, yaitu pelayanan yang dapat mendorong peran serta masyarakat dengan memperhatikan aspirasi, kebutuhan dan harapan masyarakat, (5) kesamaan hak, yaitu pelayanan yang tidak melakukan deskriminasi dilihat dari aspek apapun khususnya suku, ras, agama, golongan, status sosial, dan. (6) keseimbangan hak dan kewajiban, yaitu pelayanan yang mempertimbangkan aspek keadilan antara pemberi penerima pelayanan publik.

\section{METODOLOGI}

Dalam penelitian ini peneliti menggunakan Metode Penelitian Kualitatif merujuk pada pendapat yang dikemukakan Fraengkel, dkk (Suharsaputra, 2012) Menyatakan bahwa penelitian yang mengkaji kualitas hubungan, kegiatan, situasi atau material disebut penelitian kualitatif, dengan penekanan kuat pada deskripsi menyeluruh dalam menggambarkan rincian segala sesuatu yang terjadi pada suatu kegiatan atau situasi. Berkaitan dengan judul yang diambil, peneliti ingin mendeskripsikan dan menjelaskan situasi yang terjadi pada pelayanan pembuatan surat keterangan tidak mampu di Kelurahan Muara Tuhup Kecamatan Laung Tuhup Kabupaten Murung Raya.
Dari hasil yang didapat di lapangan, melalui Wawancara, Observasi dan Dokumentasi maka penulis merasa ada beberapa hal yang belum Maksimal dalam Kualitas Pelayanan pembuatan Surat Keterangan Tidak Mampu di Kelurahan Muara Tuhup Kecamatan Laung Tuhup Kabupaten Murung Raya.

\section{Tangible (Berwujud)}

Penampilan Pegawai Dalam Memberikan Pelayanan

Dilihat dari hasil di atas Penampilan pegawai dalam memberikan pelayanan hal tersebut sudah cukup baik dilakukan oleh Kelurahan Muara. Hal ini juga bisa dibuktikan pegawai Kelurahan Muara Tuhup menggunakan saragam lengkap beserta atribut dan juga jenis pakai sudah sesuai aturan.

Kenyaman Tempat Pelayanan

Dilihat dari hasil di atas dari segi kenyamanan tempat pelayanan masih belum maksimal. Hal ini bisa dilihat kebersihan dan kerapian tempat pelayanan Kelurahan Muara Tuhup apabila saat hujan tempat pelayanan agak sedikit kotor. Selanjutnya kondisi ruang tunggu pelayanan seperti tempat duduk dan tempat menulis kondisi tempat duduk di Kelurahan Muara Tuhup Masih terbatas apabila masyarakat banyak melakukan pelayanan sebagian masyarakat berdiri menunggu pelayanan karena terbatas tempat duduk dan juga tempat untuk menulis hanya ada satu.

Kemudahan Dalam Proses Pelayanan

Dilihat dari hasil di atas dari segi kemudahan dalam proses pelayanan ada beberapa hal yang cukup bagus namun ada juga yang belum maksimal. Pihak Kelurahan Muara Tuhup dalam bentuk apa saja kemudahan yang diberikan dalam proses pelayanan dengan memberikan kemudahan dalam bentuk informasi dan juga khususnya pembuatan SKTM masyarakat hanya menggunakan rekomendasi dari Rt saja langsung Pihak Kelurahan Muara Tuhup proses hal ini sudah cukup baik.

\section{HASIL DAN PEMBAHASAN}


Kemudahan Akses Pelanggan Dalam Permohonan Pelayanan

Dilihat dari hasil di atas dari segi kemudahan akses pelanggan dalam permohonan pelayanan kualitas pelayanan yaitu dimensi Tangible (Berwujud) pihak Kelurahan Muara Tuhup sudah menerapakan dimensi Tangible (Berwujud) tersebut hal ini juga bisa dibuktikan dengan masyarakat mudah untuk mendapatkan informasi pelayanan Pihak kelurahan Muara tuhup selalu menempel informasi di setiap RT dan masyarakat tidak memiliki kendala dengan hal tersebut.

\section{Kedisiplinan Pegawai Dalam Melakukan Proses Pelayanan}

Pihak Kelurahan Muara Tuhup tentang peraturan yang dibuat oleh Kelurahan Muara Tuhup pelayanan dari jam 8 pagi sampai siang jam 12 istirahat di lanjutkan lagi jam I sampai jam 3 sore sudah cukup bagus. Namun dari kedisiplan pegawai saat melayani masyarakat masih belum maksimal apabila hari hujan pegawai telat datang ke Kelurahan Muara Tuhup. Namun pihak kelurahan Muara Tuhup sudah melakukan tindakan untuk meningkatkan disiplin pegawai melakukan pengecekan setiap pagi, sore dan mengabsen pegawai menggunakan absen tertulis atau tanda tangan hal tersebut sudah cukup bagus.

Proses Pelayanan Pegawai Menggunakan Alat Bantu

Dilihat dari hasil di atas dari segi Proses pelayanan pegawai menggunakan alat bantu masih belum maksimal hal ini tidak sejalan dengan teori kualitas pelayanan yaitu dimensi Tangible (Berwujud) pihak Kelurahan Muara Tuhup belum bisa menerapakan dimensi Tangible (Berwujud) hal ini bisa dilihat jumlah peralatan yang digunakan dalam proses pelayanan Kelurahan Muara Tuhup masih sedikit ini bisa dilihat dari jumlah peralatan pelayanan hanya memiliki 2 komputer dan 2 printer hal ini belum maksimal dalam memberikan pelayanan.

\section{Dimensi Reliability (Kehandalan)}

Standar Pelayanan Yang Jelas
Standar Pelayanan yang Jelas masih belum maksimal hal ini tidak sejalan dengan teori kualitas pelayanan yaitu dimensi Reliabilty (Kehandalan) pihak Kelurahan Muara Tuhup belum bisa menerapakan dimensi Reliabilty (Kehandalan) hal ini bisa dilihat pihak Kulurahan Muara Tuhup tidak memiliki SOP (standar Operasional Prosedur) yang tertulis.

Kemampuan Pegawai Dalam Menggunakan Alat Bantu Yang Proses Pelayanan

Dilihat dari hasil di atas dari segi Kemampuan Pegawai Dalam Menggunakan Alat Bantu Proses Pelayanan masih belum maksimal hal ini tidak sejalan dengan teori kualitas pelayanan yaitu dimensi Reliabilty (Kehandalan) pihak Kelurahan Muara Tuhup belum bisa menerapakan dimensi Reliabilty (Kehandalan). Hal ini bisa dilihat pihak petugas pelayanan tidak pernah mengikuti diklat dan Pendidikan lanjutan. Selanjutnya dari kemampuan menggunakan alat bantu pelayanan petugas yang memberikan pelayanan kurang memiliki kemampuan menggunakan alat seperti komputer dalam memberikan pelayanan hal ini membuat pelayanan jadi lambat dan juga yang memberikan pelayanan khusus SKTM hanya satu petugas.

\section{Dimensi Responsiviness (Respon / Ketanggapan)}

Respon Atau Tanggapan Dalam Menanggapi Keluhan Pengguna Layanan

Dilihat dari hasil di atas dari segi respon atau tanggapan dalam menanggapi keluhan penggunaan pelayanan Pelayanan masih belum maksimal. Hal ini bisa dilihat apakah pegawai memberikan tindakan cepat saat masyarakat ingin melakukan pelayan pihak Kelurahan Muara Tuhup sudah cukup cepat akan tetapi jumlah yang pegawai yang memberikan pelayanan SKTM hanya satu orang hal tersebut masih kurang maksimal dalam memberikan pelayanan dan hal tersebut itu yang sering membuat masyarakat mengeluhkan pelayanan pembuatan SKTM. 
Pegawai Layanan Sudah Melakukan Pelayanan Dengan Cepat Dan Tepat

Pihak Kelurahan Muara Tuhup sudah menerapkan langkah agar cepat dan tepat melakukan pelayanan yaitu dengan cara pihak masyarakat minta direkomendasikan dari Rt masing untuk mempercepat melakukan pelayanan sehingga langsung di buatkan oleh Pihak Kelurahan Muara Tuhup. Namun masyarakat banyak yang mengeluhkan pihak yang melayani pembuatan SKTM di Kelurahan Muara Tuhup hanya satu orang pegawai sehingga membuat masyarakat menunggu lama dalam pembuatan SKTM.

Melayani Dengan Tepat Waktu Dalam Proses Pelayanan

Hal ini bisa dilihat ketepatan waktu memberikan pelayanan pihak Kelurahan Muara Tuhup tidak tepat waktu dalam melakukan pelayanan hal ini banyak disampaikan oleh masyarakat. Selanjutnya tindakan yang dilakukan menyampaikan kepada masyarakat selalu melengkapi persyaratan agar tidak menunda pelayanan. Kendala yang sering terjadi di masyarakat sering kurang persyaratan dan juga pegawai yang memberikan pelayanan sktm hanya satu orang pegawai saja sehingga lambat dalam memberikan pelayanan.

\section{Dimensi Assurance (Jaminan)}

Jaminan Tepat Waktu Dalam Pelayanan

Dilihat dari hasil di atas dari segi Jaminan Tepat waktu pelayanan ada beberapa hal yang cukup bagus namun ada juga yang belum maksimal di lihat dari teori kualitas pelayanan yaitu Dimensi Assurance (Jaminan). Hal ini bisa dilihat dari pihak Kelurahan Muara Tuhup menjanjikan 2 hari untuk pembuatan SKTM akan tetapi pihak Kelurahan Muara Tuhup tidak bisa menyelesaikan hal tersebut hal ini belum maksimal yang diberikan oleh Kelurahan Muara Tuhup.

Jaminan Biaya Pelayanan

Dilihat dari hasil di atas dari segi jaminan Biaya Pelayanan pihak Kelurahan Muara Tuhup tidak memungut biaya pembuatan Surat Keterangan Tidak Mampu hal ini membuat masyarakat tertarik membuat Surat Keterangan Tidak Mampu.

Legalitas Dalam Pelayanan

Dilihat dari hasil di atas dari segi legalitas dalam pelayanan yang diberikan oleh pihak Kelurahan Muara Tuhup berupa Surat yang di keluarkan langsung oleh pihak Kelurahan Muara Tuhup dan di tanda tangani oleh Lurah Muara Tuhup.

\section{Dimensi Emphaty (Empati)}

Pegawai Memberikan Pelayanan Dengan Sikap Ramah

Dilihat dari hasil di atas dari segi Pegawai memberikan pelayanan dengan sikap ramah sudah cukup baik hal ini sejalan dengan teori kualitas pelayanan yaitu Dimensi Emphaty (Empati) pihak Kelurahan Muara Tuhup sudah menerapakan Dimensi Emphaty (Empati) tersebut hal ini juga bisa dibuktikan pihak pegawai selalu ramah dalam memberikan pelayanan hal ini banyak disampaikan oleh masyarakat dengan sikap ramah ini akan membuat pelayanan menjadi lebih baik lagi.

Melayani Dengan Tidak Diskriminatif Atau Membedakan

Dilihat dari hasil di atas dari segi Melayani dengan tidak diskriminatif atau membedakan sudah cukup baik hal ini sejalan dengan teori kualitas pelayanan yaitu Dimensi Emphaty (Empati) pihak Kelurahan Muara Tuhup sudah menerapakan Dimensi Emphaty (Empati) tersebut hal ini juga bisa dibuktikan pihak pegawai tidak membedabedakan setiap masyarakat yang datang melakukan pelayanan diberikan perlakuan yang sama dalam memberikan pelayanan hal ini banyak disampaikan oleh masyarakat dan hal tersebut membuat pelayanan meningkat banyak masyarakat melakukan pelayanan.

\section{KESIMPULAN}

Kualitas Pelayanan pelayanan pembuatan Surat Keterangan Tidak Mampu di Kelurahan Muara Tuhup Kecamatan Laung Tuhup Kabupaten Murung Raya masih 
belum maksimal hal ini dapat dilihat dari Tangible (Berwujud) dilihat dari kenyamanan tempat pelayanan masih belum maksimal tentang kebersihan dan kerapian tempat pelayanan apabila saat hujan tempat pelayanan agak sedikit kotor. Selanjutnya kondisi tempat duduk masih terbatas apabila masyarakat banyak melakukan pelayanan sebagian masyarakat berdiri menunggu pelayanan karena terbatas tempat duduk dan juga tempat untuk menulis hanya ada satu. Dimensi Reliability (Kehandalan) dilihat dari standar pelayanan yang jelas masih belum maksimal ini bisa dilihat dari pihak Kulurahan Muara Tuhup tidak memiliki sop yang tertulis. Selanjutnya dari target pelayanan pihak Kelurahan Muara Tuhup menjanjikan dua hari untuk menyelesaikan Surat Keterangan Tidak Mampu akan tetapi pihak Kelurahan Muara Tuhup tidak bisa menyelesaikan dalam dua hari. Dari sisi Dimensi Responsiviness (Respon/ Ketanggapan) dilihat dari respon atau tanggapan dalam menanggapi keluhan penggunaan pelayanan. Pelayanan masih belum maksimal hal ini bisa dilihat pegawai yang memberikan pelayanan masih lambat ini di karenakan jumlah yang pegawai yang memberikan pelayanan sktm hanya satu orang hal tersebut itu yang sering membuat masyarakat mengeluhkan pelayanan pembuatan Surat Keterangan Tidak Mampu. Kemudian dilanjutkan Dimensi Assurance (Jaminan) dilihat dari jaminan tepat waktu pelayanan ada beberapa hal yang belum maksimal hal ini bisa dilihat dari pihak Kelurahan Muara Tuhup menjanjikan 2 hari untuk pembuatan Surat Keterangan Tidak Mampu akan tetapi pihak Kelurahan Muara Tuhup tidak bisa menyelesaikan hal tersebut hal ini belum maksimal yang diberikan oleh Kelurahan Muara Tuhup.

\section{REFERENSI}

Amsyah, Zulkifli. 2005. Manajemen Kearsipan. Jakarta: Gramedia Pustaka Utara

Barthos, Basir. 2013. Manajemen Kearsipan untuk Lembaga Negara, Swasta, dan Perguruan Tinggi. Jakarta: Bumi Aksara.
Emzir. 2012. Metodologi Penelitian Kualitatif. Jakarta: Rajawali Pers.

Ghony, Dzunaidi dan Fauzan Almansyur. 2012. Metodologi Penelitian Kualitatif. Yogyakarta: Bumi Aksara.

Gie, The Liang. 1996. Administrasi Perkantoran Modern. Yogyakarta: Liberty Yogyakarta.

Martono, Boedi. 1994. Penyusutan dan Pengamanan Arsip Vital dalam Manajemen Kearsipan. Jakarta: Midas Surya Grafindo

Nuraida, Ida. 20I2. Manajemen Administrasi Perkantoran. Yogyakarta: Kanisius

Peraturan Daerah Kota Palangka Raya Nomor 5 Tahun 2016 tentang Penyelenggaraan Kearsipan

Priansa, Donni Joni dan Agus Garnida. 2013. Manajemen Perkantoran Efektif efesien dan Profesional. Bandung: Alfabeta.

Rosmilawati, S. 2017. Peran Radio Republik Indonesia (RRI) Palangka Raya dalam Media Komunikasi Politik di Kalimantan Tengah. Restorica: Jurnal Ilmiah Ilmu Administrasi Negara dan Ilmu Komunikasi. 3(I):I26-I33.

Sugiarto, Agus dan Teguh Wahyono. 2005. Manajemen Kearsipan Modern dari Konvensional ke Basis Komputer. Yogyakarta: Gava Media.

Sugiarto, Agus dan Teguh Wahyono. 2015. Manajemen Kearsipan Modern dari Konvensional ke Basis Komputer. Yogyakarta: Gava Media.

Sugiyono. 20I4. Memahami Penelitian Kualitatif. Bandung: Alfabeta.

Wursanto. 2017. Kearsipan 2. Yogyakarta: Kanisius

Yatimah, Dorotul. 2009. Kesekretarisan Modern dan Administrasi Perkantoran. Bandung: Pustaka Setia

Yusuf, M., Nuraini, A. 2016. Implementasi Peraturan Daerah Nomor 10 Tahun 2014 tentang Pajak Reklame pada Dinas Cipta Karya, Tata Ruang dan Perumahan Kota Palangka Raya. Pencerah Publik. 3(2):33-38.

Undang-Undang Nomor 43 Tahun 2009 tentang Kearsipan. 